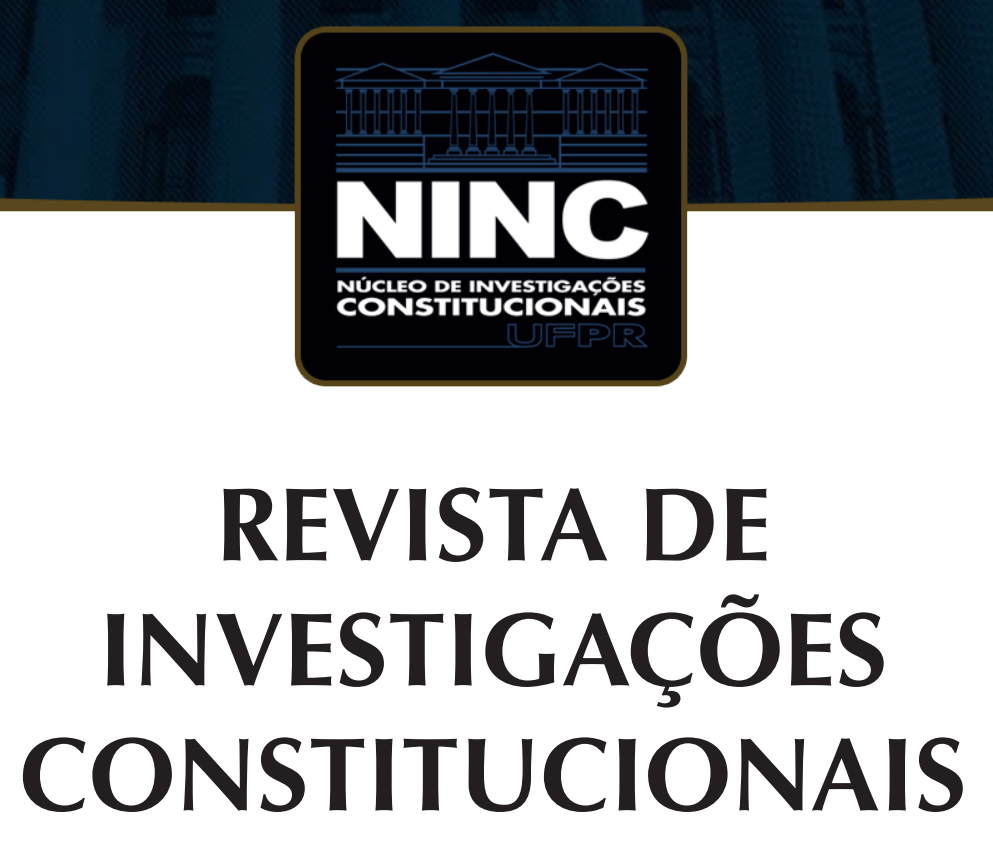

JOURNAL OF CONSTITUTIONAL RESEARCH

vol. 7 | n. 3 | setembro/dezembro 2020 | ISSN 2359-5639 | Periodicidade quadrimestral Curitiba | Núcleo de Investigações Constitucionais da UFPR | www.ninc.com.br 


\title{
Constitutional dismemberment via referenda: a comparative overview
}

\section{Desmembramento constitucional através de referendos: uma visão comparativa}

\author{
VALENTINA RITA SCOTTI I, * \\ ' Koç University (Istanbul, Turkey) \\ vscotti@ku.edu.tr \\ http://orcid.org/0000-0002-2733-476X \\ Recebido/Received: 04.06 .2020 / June $4^{\text {th }}, 2020$ \\ Aprovado/Approved: 30.10 .2020 / October 30 ${ }^{\text {th }}, 2020$
}

\begin{abstract}
Constitutional dismemberment is one of the main consequences attached to constitutional amendments that Albert's book analyses. After having analyzed Albert's definition, the present essay focuses on the practice of constitutional dismemberment via referendum and discusses whether, in times of populism and democratic decay, the constitutional design should provide for specific measures in order to protect the political opposition from the allegiance between the populist leadership and the majority of the population. Building on the existing literature and on a comparative analysis, the essay concludes by highlighting the pros and cons of introducing special protections for political minorities during constitutional referenda to protect democracy against populist deviations, suggesting the need to provide further studies in this field.
\end{abstract}

Keywords: constitutional amendments; referendum; Rule of Law; constitutional dismemberment; populism.

\section{Resumo}

O desmembramento constitucional é uma das principais consequências associadas às emendas constitucionais que o livro de Albert analisa. Depois de analisar a definição de Albert, o presente ensaio focaliza a prática do desmembramento constitucional por referendo e discute se, em tempos de populismo e decadência democrática, o desenho constitucional deve prever medidas específicas para proteger a oposição política da aliança entre a liderança populista e a maioria da população. Com base na literatura existente e em uma análise comparativa, o ensaio conclui destacando os prós e contras da introdução de proteções especiais para as minorias políticas durante os referendos constitucionais para proteger a democracia contra os desvios populistas, sugerindo a necessidade de fornecer mais estudos nesse campo.

Palavras-chave: emendas constitucionais; referendo; Estado de Direito, desmembramento constitucional; populismo.

Como citar esse artigo/How to cite this article: SCOTTI, Valentina Rita. Constitutional dismemberment via referenda: a comparative overview. Revista de Investigações Constitucionais, Curitiba, vol. 7, n. 3, p. 795-811, set./dez. 2020. DOI: 10.5380/rinc.v7i3.74334.

" Post-doctoral fellow in Comparative Public Law at Koç University School of Law (Istanbul, Turkey). Ph.D. at the University of Siena (Siena, Italy). E-mail: vscotti@ku.edu.tr. 


\section{CONTENTS}

1. Constitutional dismemberment and populist referenda: is there a risk of democratic decay?; 2. Populism and Constitutional Change; 2.1 The Role of Political Opposition in Constitutional Dismemberment; 3. Concluding remarks; 4 . References.

\section{CONSTITUTIONAL DISMEMBERMENT AND POPULIST REFE- RENDA: IS THERE A RISK OF DEMOCRATIC DECAY?}

Albert's notion of constitutional dismemberment ${ }^{1}$ introduces in the scholarship on constitutional change a category in between constitution-making and constitutional amendment, the former entailing the exercise of the constituent power while the latter encompassing a wide range of interventions on the fundamental Charter, from mere adjustments to revolutionary changes. With the constitutional dismemberment, therefore, Albert provides a denomination for those amendments implying a significant transformative behavior, notwithstanding how many articles are formally 'transformed', which constitutional aspects they discipline (i.e. constitution's identity, catalog of fundamental rights, constitution's central structural pillar), and whether the amendments aim at disrupting or restoring the core of the Constitution. This transformation can occur suddenly or gradually, but it never breaks legal continuity and it is realized with all the relevant actors' awareness about the impact it is going to have on one or more Constitution's elemental parts. In brief, for Albert, a 'simple' amendment "must cohere with the existing constitution and must keep the constitution consistent with its pre-change form,"2 while a constitutional dismemberment, either enhancing or weakening democracy, ${ }^{3}$ does not.

In times of populism, however, the impact of constitutional amendments on democracy should be carefully taken into account. Indeed, populism, magnifying the role of the will of the people, can jeopardize the Courts' power to protect the essential elements of a constitution, and, enhancing the link between the leader and the population while weakening the one between the latter and its representatives in the Assemblies, can marginalize the political opposition, moreover when the procedure for constitutional dismemberment entails a referendum.

\footnotetext{
ALBERT, Richard. Constitutional Amendment and Dismemberment. Yale Journal of International Law, vol. 43, n. 1, 2018; ALBERT, Richard. Constitutional amendments: making, breaking, and changing constitutions. Oxford: Oxford University Press, 2019. passim.

2 ALBERT, Richard. Constitutional amendments: making, breaking, and changing constitutions. Oxford: Oxford University Press, 2019. p. 82.

3 ALBERT, Richard. Constitutional amendments: making, breaking, and changing constitutions. Oxford: Oxford University Press, 2019. p. 78.
} 
Entrenched in contemporary constitutionalism as a device for calling people to decide, ${ }^{4}$ the referendum has often been the tool for instating plebiscitarian democracies. ${ }^{5}$ Indeed, referenda foster a majoritarian governance ${ }^{6}$ and populist leaders recur to them aware that individuals mostly prize charisma more than accurate explanations about the referendum's real content ${ }^{7}$ because they lack technical competences for taking relevant political decisions ${ }^{8}$. Hence, although representative democracy is not immune from majoritarian derives, ${ }^{9}$ referenda are exploited for achieving majoritarian decision-making ${ }^{10}$ moreover in a political environment with strong societal divides.

In this regard, Albert states that the reason for establishing formal rules for constitutional amendments is to reinforce the democratic debate, ${ }^{11}$ and that, because of its content, "the execution and legitimation of a constitutional dismemberment should require a greater degree of consent than a constitutional amendment".12 To ensure such a greater degree, however, he relies on the existing features constitutional designers have proposed. At the state of the art, a'selective rigidity' of the Constitution and/or the Courts' power to strike down unconstitutional constitutional amendments have been entrenched in the Charters. ${ }^{13}$ However, the legal doctrine has already underscored the

\footnotetext{
4 SUKSI, Marku. Bringing in the people: a comparison of constitutional forms and practices of the referendum. Leida: Martinus Nijhoff Publishers, 1993. p. 2.

5 See DICEY, Albert Venn. Ought the referendum to be introduced into England. Contemporary Review, 1890; DE BENOIST, Alain. Démocratie: le problème. Paris : Le Labyrinthe, 1985; MUELLER, Dennis C. Constitutional Democracy. Oxford: Oxford University Press, 1996; MAYORGA, Rene Antonio. Outsider and Neopopulism: the road to plebiscitary democracy. In: MAINWARING, Scott (Coord.). The Crisis of Democratic Representation in the Andes. Redwood: Stanford University Press, 2006; QVORTRUP, Mads. Are Referendums Controlled and Pro-hegemonic? Political Studies, vol. 48, pp. 821-826, 2000.
}

6 See LIJPHART, Arend. Democracies. Patterns of Majoritarian and Consensus Government in Twenty-One Countries. New Haven: Yale University Press, 1984. p. 204.

OAKESHOTT, Michael. Rationalism in Politics and other Essays. Indianapolis: Liberty Fund, 1991. p. 380. See also TIERNEY, Stephen. Constitutional Referendums: The Theory and Practice of Republican Deliberation. Oxford: Oxford University Press, 2012. p. 28.

8 This is because whether the answer is relatively easy (YES or NO), the question may be complex, and therefore people's perception of it can be maneuvered using the ideological bond between the people and political parties. See SARTORI, Giovanni. The Theory of Democracy Revisited. New York: Chatham House, 1987. p. 120, SETALA, Maija. On the problems of responsibility and accountability in referendums. European Journal of Political Research, n. 45, 2006. p. 699; SEMETKO, Holli A.; DE VREESE, Claes E. (Coord.). Political Campaigning in Referendums: Framing the Referendum Issue. London: Routledge, 2004.

9 TIERNEY, Stephen. Constitutional Referendums: The Theory and Practice of Republican Deliberation. Oxford: Oxford University Press, 2012. p. 39-40.

10 The risks for minorities deriving from referenda were already debated in MILL, John Stuart. Considerations on Representative Government [1862]. New York: Prometheus Books, 1991 and in MADISON, James. Federalist Paper No 10.

11 ALBERT, Richard. Constitutional amendments: making, breaking, and changing constitutions. Oxford: Oxford University Press, 2019. p. 46.

12 ALBERT, Richard. Constitutional amendments: making, breaking, and changing constitutions. Oxford: Oxford University Press, 2019. p. 92.

13 LANDAU, David; DIXON, Rosalind. Constraining Constitutional Change. Wake Forest Law Review, vol. 50, n. 4, p. 859-890, 2015. 
potential weakness of these design mechanisms - as well as of the 'militant democracy' against current authoritarian threats - and has called for greater scholarly attention in analyzing the links between constitutionalism and democracy. ${ }^{14}$

Against this background, forms for protecting political minorities in times of democratic decay should not be underestimated among the tools for disciplining constitutional change. Populism may indeed nullify the usually required parliamentary super-majorities or the other devices at the parliamentary level thought for increasing the negotiation, given also the fact that most of the Constitutions require a smaller qualified majority if a referendum will follow. In this vein, Landau proposes to introduce the requirement of multiple votes and intervening elections between votes for the constitutional dismemberment believing that a bigger time span can reduce the risks of abusive constitutional practices. This paper discusses the feasibility of another tool. Building on the comparative study of cases in which populist forces abridged political opposition and achieved to weaken the Constitution's democratic identity by calling for a popular referendum, here the introduction of an explicitly reserved quota for political opposition in the requested super-majority for the approval of the dismemberment is examined.

\section{POPULISM AND CONSTITUTIONAL CHANGE}

Political scientists consistently struggle to find a definition of populism. For the scope of this contribution, populism can be defined as an ideology opposing the pure people against corrupted elite, ${ }^{15}$ with a specific communication style ${ }^{16}$ and a strategy for gaining and then keeping the power. ${ }^{17}$ In this strategy, populist parties exploit the promise, both right-wing and left-wing populism present with messianic tones and with a salvific attitude, to ensure the respect of the people's real will for obtaining huge parliamentary majorities, then allowing them to monopolize the agenda-setting and the law-making process without needing to bargain with opposition parties. At this aim, constitutional change, either via constitution-making or constitutional dismemberment, is the most used tool. ${ }^{18}$

When amendment procedures set for a referendum after a parliamentary approval with a minimum qualified majority, thanks to the super-majority they own,

\footnotetext{
14 LANDAU, David. Abusive Constitutionalism. UC Davis Law Review, n. 47, p. 189-260, 2013.

15 MUDDE, Cas. The Populist Zeitgeist. Government and Opposition, n. 39, p. 541-543, 2004.

16 JAGERS, Jan; WALGRAVE, Stefaan. Populism as Political Communication Style: An Empirical Study of Political Parties' Discourse in Belgium. European Journal of Political Research, vol. 46, n. 3, p. 319-345, 2007.

17 WEYLAND, Kurt. Clarifying a Contested Concept - Populism in the Study of Latin American Politics. Journal of Comparative Politics, vol. 34, n. 1, p. 1-22, 2001.

18 LANDAU, David. Populist Constitutions. The University of Chicago Law Review, Chicago, vol. 85, n. 2, p. 521-544, 2018.
} 
populist parties have thus a chance for proceeding to a constitutional dismemberment without consulting/negotiating with other actors. Should this happen, the judicial review of constitutional amendments is the only remaining device for safeguarding the constitutional identity from unconstitutional amendments. Nevertheless, the doctrine has already underscored that only a few legal systems allow for this review, that some limit it to formal aspects and that a general critique can raise about the democracy of this procedure exactly because it safeguards constitutionalism at the expense of the respect of people's will. ${ }^{19}$ Populists' defiance toward Courts and notably toward constitutional judges stems from this paradox.

Furthermore, in a populist political environment, the main teleological aim of reinforced provisions for amending rigid constitutions - which is to preserve the fundamental Charter from volatile majorities and to include the opposition in such high-level decision-making - is generally disregarded as long as the focus is to fulfill the will of the present majority. Besides the risk of the tyranny of the (representative) majority, there is also the fact that the (popular) majority can be not so huge and, when a specific requirement for the turnout is not provided, the outcome of the referendum can then be determined by the sole will of an active political minority.

Finally, it should be noted that when the people's will concerns elections, the implementation of the political program presented and the 'evaluation' people will provide in the subsequent elections represent an incentive for politicians for being realistic and accountable. A referendum, instead, is a one-time event with no-specific consequences deriving from the way political forces campaigned, therefore they may have no incentives for being accountable and clearly represent/campaign on the content of the referendum.

Notwithstanding whether people's final decision has been in favor of or against populists' expectations, several examples of opposition's abridgment during attempts of constitutional dismemberment via referendum exist. Believing that the instability of constitution-making is the cost that must be paid when (re-)writing the Charter and that "the greater role granted to popular referenda and extra-parliamentary authorities, the less constitutionalism matters as a political force", 20 the cases discussed below showcase the risks for the political opposition during constitutional dismemberments when devoted protection lacks.

19 ROZNAI, Yaniv. Unconstitutional Constitutional Amendments. Oxford: Oxford University Press, 2017.

20 HOLMES, Stephen T.; SUNSTEIN, Cass R. The Politics of Constitutional Revision in Eastern Europe. In: SANFORD, Levinson (Coord.). Responding to imperfection: the theory and practice of Constitutional Amendment. Princeton: Princeton University Press, 1995. p. 275-290. 


\subsection{The role of political opposition in constitutional dismember- ment}

Albert hints at the use of referenda for circumventing the role of the opposition when examining the 1962 French referendum for amending the rules for presidential elections originally provided in the 1958 Constitution. On that occasion, De Gaulle convened a referendum (art. 11 Const.) and exploited his political influence on the population for having the direct election approved, aware that he could not gather the required majority in Parliament.

Several other cases in which the relationship between the leader and the population has been exploited for constitutional changes, often entailing a clear constitutional dismemberment, can be listed. As Albert briefly mentions, Turkey is among the countries where constitutional dismemberment can be observed; ${ }^{21}$ also, it is a country where the abridgment of the political opposition via referendum proved successful due to a solid pro-hegemonic dynamic of popular consultations. ${ }^{22}$ Indeed, Albert reports the case of the 2017 constitutional amendment, having entailed the rewriting or repealing of around 40 percent of the 1982 Charter. The reform, which builds on the 2007 constitutional amendment introducing the direct election of the President of the Republic, has changed the form of government from parliamentarism to a presidentialism turning the country into a majoritarian democracy and extensively increasing the power of the President of the Republic. ${ }^{23}$ In both the 2007 and 2017 amendments, the modifications of the form of government needed the popular confirmation via referendum and impinged on the constitution's identity to an extent that let include them among constitutional dismemberments. In both the 2007 and 2017 amendments, incumbents proved aware of this.

Nevertheless, in 2007, the referendum was convened in a residual attempt of avoiding dismemberment, while in 2017 it was a means for ensuring people's support to the change of the constitutional identity while abridging the parliamentary opposition. Indeed, in 2007, President Sezer convened the referendum in order to hamper the entry into force of the constitutional amendment for the direct election of the President of the Republic the AKP majority in the Grand National Assembly of Turkey (GNAT) approved - although not with the required majority for avoiding the referendum - when the CHP opposition proved able to obstruct the election of Abdullah Gül as the President of the Republic. In the letter explaining the reasons for sending back to

21 ALBERT, Richard. Constitutional amendments: making, breaking, and changing constitutions. Oxford: Oxford University Press, 2019. p. 85.

22 In this regard, it is worthy to underscore that Turks have always confirmed, though with different majorities, constitutional amendments proposed by the AKP government.

23 SCOTTI, Valentina Rita. On the pro-hegemonic nature of referenda for constitutional reforms in Turkey. A focus on 16 April 2017 referendum introducing presidentialism. Osservatorio Costituzionale, n. 2, 2017. 
the GNAT the amendment bill for reconsideration, President Sezer stated that the direct election would have altered the pillars of parliamentarism, and namely the impartiality of the office, on which the Republic was built since its establishment. ${ }^{24}$ Although envisaging the risks, Sezer could only rely on the people, who however confirmed the pro-hegemonic nature of referenda and approved the dismemberment. In 2017, instead, the President of the Republic Erdoğan convened the referendum because the amendment bill obtained only 330 votes, lacking the 367 votes on 550 needed for direct entry into force (article 175 of the Constitution). The populist antagonism between the people and the elite, as well as the lack of a political culture based on pluralism, clearly appeared in this circumstance. Indeed, Erdoğan stated that "These people (the opposition) don't have respect for the people or popular sovereignty. Remember the slogan: one people, one flag, one homeland, one state". 25 The opposition surrendered to the leader/people relationship and the leader of the opposition party CHP, Kemal Kılıçdaroğlu, while explaining the decision of not appealing the Constitutional Court, ${ }^{26}$ stated that "A sovereignty that cannot be protected by the people's will is not possible to be protected by any other power. [...] If the issue is the nation's sovereignty, the real Supreme Court in that case is the people's, nation's court". ${ }^{27}$ The peculiar political atmosphere of the post-July-2016 state of emergency - still into force at the time of the referendum - contributes to explaining this submissive approach.

Finally, it is important to underscore that the demotion of the political opposition during constitutional amendments' negotiations, though increased during the AKP era, was in the intent of the framers of an amendment passed at the end of the '80s. Indeed, in the original 1982 Constitution, a two-thirds majority of the MPs in the GNAT should approve amendment proposals, the President of the Republic is entitled to return the amendment bill for reconsideration, and, in case it is re-adopted without change, he can submit it to a popular referendum (article 175). ${ }^{28}$ However, in 1987, believing this procedure too rigid and unable to overcome parliamentary deadlocks, the Prime Minister Turgut Özal supported the approval of a constitutional amendment on

24 For further details on the introduction of the direct election, see ÖRÜCÜ, Esin. Whither the Presidency of the Republic of Turkey? European Public Law, n. 14, p. 35-53, 2008. p. 48.

25 ERDOĞAN, Recep Tayyip. Yenikapı'da tarihi bulus, mada tarihi mesajlar. Sabah, April 8, 2017.

26 It is noteworthy that, whether appealed, the Constitutional Court could have declared the amendment unconstitutional. However, it should be also noted that the Court has progressively reduced its activism in this regard since the 2010 constitutional amendment having overloaded the Constitutional Court with the introduction of individual applications for rights violation and increased the number of judges elected thanks to the allegiance with the AKP environment.

27 Main opposition CHP won't appeal the presidential system reform before Turkey's top court, in Daily Sabah, 14 February 2017.

28 Ozbudun states that "This was in line with the Constitution's general philosophy of strengthening the Presidency as an 'impartial arbiter'.', in ÖZBUDUN, Ergun. The Constitutional System of Turkey: 1876 to the Present. New York: Palgrave-Macmillan, 2011. 
constitutional revisions according to which, should the amendment bill be adopted by at least three-fifths but less than two-thirds majority of MPs and if it is not returned by the President for reconsideration, the amendment shall be submitted to a mandatory popular referendum. If it is returned for reconsideration but is re-approved by a twothirds majority, then the President may discretionally decide whether to submit the bill to a referendum.

Özal's will was to avoid that opposition's obstructionism could hamper the approval of an amendment. The reform of the form of government perfectly fitted the matter. Initially, the Constitutional Commission for Reconciliation was established for having the reform of the 1982 Constitution negotiated in a pluralistic way. Nevertheless, when presidentialism emerged has an AKP's priority and the opposition highly contested its introduction, negotiations were put aside and the parliamentary majority plus referendum was considered a valid and viable procedure as well.

It is finally noteworthy that opposition's abridgment has occurred, though more subtly, also when unamendable provisions were questioned. ${ }^{29}$ Indeed, when the Constitutional Court declared the unconstitutionality of the amendment bill reforming articles 10 and 42 of the Constitution for allowing female students to wear the veil because it infringed Turkish secularism, ${ }^{30}$ the Executive apparently respected the judicial decision, but then de facto overruled it through legislative or administrative measures it could approve without having to follow the procedure and the rules for a formal amendment.

The use of referendum for constitutional dismemberment to circumvent the opposition is evident also in the 2009 amendment to the 1999 Constitution of Venezuela the then populist President Hugo Chavez promoted for abolishing the term limit for all elected offices. ${ }^{31}$ This amendment strongly altered an element of the Venezuelan constitutional identity established since the 1830 Constitution $^{32}$ and confirmed in the 1999 Charter. To appreciate the democratic backsliding connected to this amendment, it should be introduced a premise on the procedures 1999 Constitution provided. Indeed,

\footnotetext{
29 According to art. 4 of 1982 Turkish Constitution, the republican nature of the state (article 1), the main characteristics of the Republic listed in article 2 (democracy, secularism, social State governed by the rule of law, public peace, national solidarity, and justice; human rights' respect; Atatürk's nationalism), the integrity of the State, its official Language, flag, national anthem and Capital (article 3) cannot be amended.

30 Constitutional Court, E2008/16 K2008/116, 5 June 2008. On the importance of this decision for the adjudication of unconstitutional constitutional amendments in the Turkish legal system, see ROZNAI Yaniv; YOLCU, Serkan. An unconstitutional constitutional amendment-The Turkish perspective: A comment on the Turkish Constitutional Court冈s headscarf decision. International Journal of Constitutional Law, vol. 10, n. 1, p. 175202, 2012.

31 The referendum was proposed after the rejection of another referendum on a constitutional amendment aimed at removing the term limit only for the presidential office, held in December 2007.

32 The only exceptions in this regard were the 1857 Constitution, the authoritarian Constitutions approved under Juan Vicente Gómez (1914-1933), and the 1953 Constitution of Marcos Pérez Jiménez.
} 
the Charter distinguished between changes safeguarding its fundamental principles or structure - to be realized through a constitutional amendment procedure (article 340) or a constitutional reform procedure (article 342), both entailing a referendum - and the alterations of the fundamental structure, to be realized through a National Constituent Assembly (article 347); finally, should a constitutional reform be rejected, a similar proposal cannot be filed again before the National Assembly in the remainder of the constitutional term (article 345). However, there is no provision on the rejection of constitutional amendments or on the possibility to file the same rejected constitutional reform proposal through the procedure of a constitutional amendment.

Thus, when Chavez proposed the amendment, which extended to all the elective offices the term limit removal he already attempted only for the Presidency in 2007, the political opposition strongly claimed that this would have meant a final consecration of authoritarianism in the country and underscored the risks of unconstitutionality connected to procedures. Nevertheless, confirming the potential subservience courts may suffer in populist divided political societies, despite the massive opposition of non-governing political forces, the Constitutional Court declared both that the proposal had to be conceived as a constitutional amendment and that the limits provided for the constitutional reform could not apply. ${ }^{33}$ In this case, the allegiance between the Executive and the Court deprived of relevance the Assembly and the role the opposition should have therein moreover when discussing constitutional dismemberments.

Among Latin America delegative democracies, ${ }^{34}$ several other examples of referenda used for circumventing the opposition in a constitutional dismemberment can be found. Ecuador is a relevant case. There, President Correa exploited the populist discourse for defeating the opposition - including the one arising from his own party - and bound the Parliament to his will. Then, in 2011, after the 2010 failed coup that narrows the psychological environment in which the Ecuadorian referendum was approved to the 2017 Turkish one, Correa asked people to approve several measures, among the others, for packing the Supreme Court and reducing freedom of the press. The 2008 Constitution of Ecuador establishes two procedures for constitutional amendments not entailing structural changes or alterations in the protection of rights and it is the Constitutional Court that indicated the procedure to be followed; the Charter also entitles the President with the power of initiative and of convening referenda for constitutional amendments (articles 441-442). ${ }^{35}$ Finally, a procedure exists for installing, via referendum, a Constituent Assembly for replacing the Charter (article 443). In the lack of a provision for a constitutional dismemberment and thanks to the subservience of

33 See Constitutional Chamber of the Supreme Tribunal of Justice, decision no. 53, 3 February 2009.

34 O'DONNELL, Guillermo. Delegative Democracy. Journal of Democracy, vol. 5, p. 55-69, 1994.

35 See Ley Orgánica de Garantías Jurisdiccionales y Control Constitucional. 
the Constitutional Court, ${ }^{36}$ Correa could use the majority in Parliament and the popular support for strongly empowering the Executive against the other state powers and for reducing fundamental freedoms' protection.

The modification of the presidential term, namely its extension as a step toward illiberal governments, has been the main reason for convening constitutional referenda in Sub-Saharan Africa. Hence, in light of the risks for the endurance of democracy, the experience of Guinea seems relevant. Indeed, in 2001, a referendum was held for extending the presidential term from 5 to 7 years, allowing the incumbent President to serve for a third term, and extending the central government's power on local authorities. The case is noteworthy because, although it proved quite fragmented, the opposition unitedly supported the claim of the Speaker of the National Assembly, El Hadj Bubacarr Biro Diallo, for a stronger involvement of the Assembly in drafting constitutional changes. The conflict among state powers can be considered as the main reason for the Executive's failure in obtaining the required parliamentary majority of two-thirds of MPs, which then made necessary the referendum. Although the opposition called for a boycott, the population confirmed the allegiance with the leader and approved the amendment, which entailed a dismemberment for its consequences on the potential alternation in the highest office. President Conte's death in 2008 opened a period of turmoil terminated with the approval via referendum of the 2010 Constitution, again establishing presidential term in 5 years. However, with March 2020 referendum, once again the population sided the leader and approved the extension of the presidential term (from 5 to 6 years), together with several amendments reinforcing the prohibition of gender-based discrimination and violence. In this case, the democratic decay can be a more than evident menace, the incumbent 80-years-old President Alpha Condè having clarified well before the referendum that the terms he already served under the previous constitutional limit in his opinion do not count. In brief, having approved the referendum, Guineans have almost ensured him 12 further years in office.

Looking at Europe, the 2016 Italian referendum is a noteworthy case of constitutional dismemberment that challenged the role of the opposition. It certainly represented an attempt of dismemberment for the modifications to the perfect bicameralism framers entrenched in the Charter to ensure meditated decisions. Italy is among the countries providing for a single procedure for all the possible constitutional changes, though multiple votes are required. Notably, each House of the Parliament must approve the constitutional amendment in two successive debates, held with intervals of not less than three months. On the second vote, both Houses must approve by an absolute majority and, if it is with less than a two-thirds majority in each of the Houses

36 In the case under examination, the Court established that the bill had to undergo the procedure for the consulta popular (see Constitutional Court of Ecuador, Rulings no. 001-11-DRC-CC and 001-DCP-CC-2011, 15 February 2011). 
on the second vote, the amendment may be subject to a referendum if either one-fifth of the MPs in each House or 500,000 voters or five regional councils so requests (article 138). In brief, the Italian Constitution seems to provide a means for the opposition to contrast an Executive-initiated constitutional amendment, as indeed occurred with the 2006 wide reform of Title $V$ of the Constitution devolving some powers to local entities. In the case of the 2016 referendum, however, both the right-wing opposition and a part of the ruling center-left party disliked the constitutional amendment bill the Executive proposed, up to the point that it was necessary to put the question of confidence to have it approved on the second vote. Putting the question of confidence on a constitutional amendment is a clear sign of the Executive's attempt to reduce the margins of negotiation on the reform of a core constitutional element. The decision of some MPs of the majority-coalition who voted in favor of the reform to request a referendum does not seem a viable tool for restoring the democratic breach and can also denounce an attempt to pass with the popular support a reform scarcely appreciated by people's representative. In the end, the referendum was not approved, probably also because of the personalization of the campaign the then Prime Minister Matteo Renzi made. ${ }^{37}$

\section{CONCLUDING REMARKS}

Albert has developed the theory of dismemberment to answer the following questions: How should constitutional designers structure the rules of constitutional change? How may political actors legally and legitimately formalize transformative changes to the constitution? How should scholars evaluate constitutional changes believed to violate the constitution's rights, structure, or identity? Should courts review the constitutionality of constitutional alterations?

Dealing with these questions, the present contribution attributed a specific role to referenda held in populist regimes, willing to study whether the constitutional design currently available can avoid the abridgment of the opposition, and the democracy backsliding it entails, moreover when the constitutional amendment in reality is a dismemberment. In this vein, the risks for democracy during constitution-making processes have not been explored, although it is questioned whether also in this case the lack of safeguard clauses can endanger democracy, as proved in the recent Hungarian experience. ${ }^{38}$ Similarly, the strength of constitutional rigidity, even in those constitutions having provided procedures nuanced according to the relevance of the amendment for the general coherence of the Charter itself, has not been examined.

37 For details on this, see BULL, Martin J. Renzi Removed. The 2016 Italian Constitutional Referendum and Its Outcome. Italian Politics, n. 1, pp. 131-153, 2017.

38 BÁNKUTi, Miklós; HALMAI, Gàbor; SCHEPPELE, Kim Lane. Hungary's Illiberal Turn: Disabling the Constitution. Journal of Democracy, vol. 23, n. 3, p. 138-46, 2012. 
Here, the focus is on the risks the absence of clauses explicitly protecting the political opposition can entail for the general endurance of democracy. Indeed, once clarified that the constitution-making process matters as well as the final content of the Charter and that this process must be inclusive, participatory, and open, ${ }^{39}$ then the same shall be valid for constitutional amendments, moreover when they touch the core of the constitution's identity.

According to Albert, a constitutional change should not be barred by the Constitution, but it also cannot go beyond the power of lawmakers and the people. Therefore, even though a transformative constitutional amendment should be allowed without taking the risk of the instability connected with a new constitution-making process, dismemberments should not occur by using the simple procedures for constitutional amendment. As Albert states, dismemberments "demand a higher level of direct or mediated popular consent since their effect is to unmake the constitution. [...] All changes should be possible without breaking legal continuity but not without gathering a higher-than-ordinary quantum of agreement from the peoples and institutions needed to legitimate transformative changes". In brief, "What validates a formal amendment is not its content alone but also the process by which it comes into existence". Though this clarifies that the procedure matters and that a special procedure should be introduced for constitutional dismemberments, yet it relies upon the current constitutional design believing that super-majorities and referendum can safeguard the respect of the democratic game.

Nevertheless, when populism enters in such a game, the issue complicates. Indeed, because "a two-thirds supermajority requirement, which may seem very demanding in the context of a competitive two-party or multiparty democracy, may not be demanding at all in a dominant party system or even after one party (as in Hungary) happens to win a high percentage of seats with a bare majority of votes" ${ }^{40}$ the possibility of providing clauses for protecting the opinion of the minorities should be discussed. In other words, what is at stake here is the risk that populist forces, having already obtained a supermajority in the Parliament, exploit the popular favor they enjoy for a constitutional dismemberment toward a less democratic constitutional identity, able to secure their power and hampering the turnover. Attributing solely to the judicial review of constitutional amendments the power of protecting the system from the violation of the democratic rules seems neither viable nor realistic, given the cases - some of them also mentioned here - in which Courts, willing or not, have sided populist Executives.

39 See HART, Vivien. Democratic Constitution-Making. US Institute of Peace-Special Report n. 107, 2003. And CHAMBERS, Simone. Democracy, Popular Sovereignty, and Constitutional Legitimacy. Constellations An International Journal of Critical and Democratic Theory, vol. 11, issue 2, p. 153-173, 2004.

40 LANDAU, David; DIXON, Rosalind. Constraining Constitutional Change. Wake Forest Law Review, vol. 50, n. 4, p. 859-890, 2015. p. 872. 
In times of populism, also the referendum fails to represent a solid device for protecting democracy because it seems to glorify - instead of containing - its main feature, that is majoritarianism, ignoring that the protection of political minorities is quintessential to democracy. Indeed, involving people's participation in the procedures for constitutional amendment has been deemed as obvious ${ }^{41}$ because it seems to add a taste of constituent power, in line with Seyes' conception that the nation's will is always legal. ${ }^{42}$ Nevertheless, the nation's will can be volatile and, moreover when facing an economic or social crisis, people may incline to sacrifice freedom and democracy in favor of political stability. Furthermore, considering the aforementioned characteristics of the referendum, asking about people's will can be tricky during populisms both in case of constitution-making - when a mandate from people is necessary ${ }^{43}$ - and of constitutional dismemberment, a fortiori whether the latter de facto means drafting a new Charter but following preordered procedures, as occurs in several Latin American countries including those mentioned here.

The examined cases instantiate the risks for political oppositions, showing that different constitutional designs could not safeguard them against populist forces. Indeed, in Turkey, where the Constitution provides a single procedure for every kind of constitutional amendment, lists a series of unamendable principles and assigns the Court an overlooking power, the procedure itself suggests the pathways for circumventing the opposition. In Venezuela and Ecuador, instead, the existence of different procedures according to the relevance of the constitutional change was not sufficient for protecting the opposition, because of the alliance between the leader and the judiciary. Guinea instantiates that constitutional provisions can always be hostages of a strong leader/ people relationship. In Italy, finally, the procedure conforms to Landau's request of multiple votes for a meditated decision, but the absence of an explicit provision prohibiting the vote of confidence on constitutional matters - and possibly the lack of a political sensibility for understanding that such decisions should be inclusive and open - constrained the debate and coerced the parliamentary vote.

Under a propositional perspective, these cases lead to a reflection and a request. The reflection is that democracy is for sure a constantly on-going process and that, though framers have tried their best, not always the tools provided in the constituent moment can foresee the challenges a legal system will have to face. Furthermore, the impact of populism on democracy should be analyzed both with reference to the

41 See, i.e., EISENSTADT, Todd A.; LEVAN, Carl A.; MABOUDI, Tofigh. When Talk Trumps Text: The Democratizing Effects of Deliberation during Constitution-making, 1974-2011. American Political Science Review, vol. 109, n. 4, p. 592-612, 2015.

42 SIEYĖS, Emmanuel-Joseph. What is the Third Estate? (Qu'est-ce que le Tiers Etat ?). London: Praeger, 1963.

43 ACKERMAN, Bruce. The future of liberal revolution. New Haven: Yale University Press, 1991. p. 53-54. 
exploitation of the democratic procedure it may realize, and having regard to its impact on aspects such as the freedom of the press and the fairness of the political campaign, which can further reduce people's ability to stand for democracy. Indeed, scholars have already demonstrated the impact of a lively and free civil society on the outcomes of referenda as well as the disruptive effects the governmental control on the public sphere may have in this regard. ${ }^{44}$ Nevertheless, experience has also proved that the main characteristic of populism is to limit the public confrontation by assuming the will of the majority supporting it as the will of the whole population, or at least of the only part of the population worthy to be considered.

These premises led to the request to deepen the studies on the role of the political opposition during constitutional dismemberment and to examine whether introducing new devices, such as the protection of political minorities, can harbor the democratic principle. Notably, about the potential constitutional design whose importance Albert underlines moreover with regard to constitutional dismemberment, it should be questioned whether it can be significant to keep the already provided majorities and super-majorities, joint with referenda, but introducing a reserved quota of opposition's approval for those amendments entailing a dismemberment. It can be anticipated that, although such a quota can be easily introduced in bipolar systems, it could be more difficult to ensure in proportional political realities. Furthermore, besides constitutional provisions, the official role a legal system assigns to political minorities calls into question the parliamentary rules of procedures; therefore, in the light of ensuring special protection to these groups during constitutional change, amendments and dismemberments, the statute of the opposition should be further studied and intertwined with the theory on constitutional change. At this stage of the research, however, the reserved quota seems to be a viable device for protecting democracy against the populist authoritarian drift, as long as it will compulsorily entail the duty of canvassing different opinions.

The aim of avoiding opposition's obstructionism, which had justified the amendment of article 165 of the Turkish Constitution, can be accepted with regard to the enactment of the political program the people awarded with their vote during elections. Yet, when fundamental constitutional tenets are endangered by a constitutional dismemberment the deliberation should be as inclusive as possible. Thence, even assuming that in some legal system the introduction of a quota would not be feasible, a guarantee for the deliberation - meant as a moment in which all the involved parties are heard and conflicting arguments are smooth out - should stem, avoiding coercion as in the aforementioned Italian question of confidence.

44 CHAMBERS, Simone. Democracy and constitutional reform: Deliberative versus populist constitutionalism. Philosophy and Social Criticism, vol. 45, n. 9-10, p. 1116-1131, 2019. 


\section{REFERENCES}

ACKERMAN, Bruce. The future of liberal revolution. New Haven: Yale University Press, 1991.

ALBERT, Richard. Constitutional Amendment and Dismemberment. Yale Journal of International Law, vol. 43, n. 1, 6, 2018.

ALBERT, Richard. Constitutional amendments: making, breaking, and changing constitutions. Oxford: Oxford University Press, 2019.

BÁNKUTI, Miklós; HALMAI, Gàbor; SCHEPPELE, Kim Lane. Hungary's Illiberal Turn: Disabling the Constitution. Journal of Democracy, vol. 23, n. 3, p. 138-46, 2012.

BULL, Martin J. Renzi Removed. The 2016 Italian Constitutional Referendum and Its Outcome. Italian Politics, n. 1, pp. 131-153, 2017.

CHAMBERS, Simone. Democracy and constitutional reform: Deliberative versus populist constitutionalism. Philosophy and Social Criticism, vol. 45, n. 9-10, p. 1116-1131, 2019.

CHAMBERS, Simone. Democracy, Popular Sovereignty, and Constitutional Legitimacy. Constellations - An International Journal of Critical and Democratic Theory, vol. 11, issue 2, p. 153-173, 2004.

DE BENOIST, Alain. Démocratie: le problème. Paris : Le Labyrinthe, 1985.

DICEY, Albert Venn. Ought the referendum to be introduced into England. Contemporary Review, 1890.

EISENSTADT, Todd A.; LEVAN, Carl A.; MABOUDI, Tofigh. When Talk Trumps Text: The Democratizing Effects of Deliberation during Constitution-making, 1974-2011. American Political Science Review, vol. 109, n. 4, p. 592-612, 2015.

ERDOĞAN, Recep Tayyip. Yenikapı'da tarihi bulus mada tarihi mesajlar. Sabah, April 8, 2017.

HART, Vivien. Democratic Constitution-Making. US Institute of Peace-Special Report n. 107, 2003.

HOLMES, Stephen T.; SUNSTEIN, Cass R. The Politics of Constitutional Revision in Eastern Europe. In: SANFORD, Levinson (Coord.). Responding to imperfection: the theory and practice of Constitutional Amendment. Princeton: Princeton University Press, 1995. p. 275-290.

JAGERS, Jan; WALGRAVE, Stefaan. Populism as Political Communication Style: An Empirical Study of Political Parties' Discourse in Belgium. European Journal of Political Research, vol. 46, n. 3, p. 319-345, 2007.

LANDAU, David. Abusive Constitutionalism. UC Davis Law Review, n. 47, p. 189-260, 2013.

LANDAU, David. Populist Constitutions. The University of Chicago Law Review, Chicago, vol. 85, n. 2, p. 521-544, 2018. 
LANDAU, David; DIXON, Rosalind. Constraining Constitutional Change. Wake Forest Law Review, vol. 50, n. 4, p. 859-890, 2015.

LIJPHART, Arend. Democracies. Patterns of Majoritarian and Consensus Government in Twenty-One Countries. New Haven: Yale University Press, 1984.

MADISON, James. Federalist Paper No 10.

MAYORGA, Rene Antonio. Outsider and Neopopulism: the road to plebiscitary democracy. In: MAINWARING, Scott (Coord.). The Crisis of Democratic Representation in the Andes. Redwood: Stanford University Press, 2006.

MILL, John Stuart. Considerations on Representative Government [1862]. New York: Prometheus Books, 1991.

MUDDE, Cas. The Populist Zeitgeist. Government and Opposition, n. 39, p. 541-543, 2004.

MUELLER, Dennis C. Constitutional Democracy. Oxford: Oxford University Press, 1996.

O'DONNELL, Guillermo. Delegative Democracy. Journal of Democracy, vol. 5, p. 55-69, 1994.

OAKESHOTT, Michael. Rationalism in Politics and other Essays. Indianapolis: Liberty Fund, 1991.

ÖRÜCÜ, Esin. Whither the Presidency of the Republic of Turkey? European Public Law, n. 14, p. 35-53, 2008.

ÖZBUDUN, Ergun. The Constitutional System of Turkey: 1876 to the Present. New York: Palgrave-Macmillan, 2011.

QVORTRUP, Mads. Are Referendums Controlled and Pro-hegemonic? Political Studies, vol. 48, pp. 821-826, 2000.

ROZNAI Yaniv; YOLCU, Serkan. An unconstitutional constitutional amendment-The Turkish perspective: A comment on the Turkish Constitutional Court囚s headscarf decision. International Journal of Constitutional Law, vol. 10, n. 1, p. 175-202, 2012.

ROZNAI, Yaniv. Unconstitutional Constitutional Amendments. Oxford: Oxford University Press, 2017.

SARTORI, Giovanni. The Theory of Democracy Revisited. New York: Chatham House, 1987.

SCOTTI, Valentina Rita. On the pro-hegemonic nature of referenda for constitutional reforms in Turkey. A focus on 16 April 2017 referendum introducing presidentialism. Osservatorio Costituzionale, n. 2, 2017.

SEMETKO, Holli A.; DE VREESE, Claes E. (Coord.). Political Campaigning in Referendums: Framing the Referendum Issue. London: Routledge, 2004.

SETALA, Maija. On the problems of responsibility and accountability in referendums. European Journal of Political Research, n. 45, 2006. 
SIEYÈS, Emmanuel-Joseph. What is the Third Estate? (Qu'est-ce que le Tiers Etat ?). London: Praeger, 1963.

SUKSI, Marku. Bringing in the people: a comparison of constitutional forms and practices of the referendum. Leida: Martinus Nijhoff Publishers, 1993.

TIERNEY, Stephen. Constitutional Referendums: The Theory and Practice of Republican Deliberation. Oxford: Oxford University Press, 2012.

WEYLAND, Kurt. Clarifying a Contested Concept - Populism in the Study of Latin American Politics. Journal of Comparative Politics, vol. 34, n. 1, p. 1-22, 2001. 